\title{
ANALISIS PENGARUH CAR, NPL, NIM, BOPO DAN LDR TERHADAP ROE PADA BANK UMUM SWASTA NASIONAL DEVISA DI INDONESIA
}

\author{
Monica \\ Program Studi Magister Manajemen Universitas Tarumanagara \\ alexmonicaaa@gmail.com
}

\begin{abstract}
This research is meant to find out the influence of Capital Adequacy Ratio (CAR), Non Performing Loan (NPL), Net Interest Margin (NIM), Biaya Operasional/Pendapatan Operasional (BOPO), and Loan to Deposit Ratio (LDR) to the Return on Equity (ROE) at Private Foreign Exchange National Bank in Indonesia. The population is all Private Foreign Exchange National Bank in Indonesia. This study has been done by using purposive sampling method with two criteria so 20 companies have been selected as samples. The analysis technique has been done by using multiple linear regressions. The results showed that CAR, NIM, and LDR did not effect to ROE, whereas NPL and BOPO has negative effect to ROE. Where it was proved that together CAR, NPL, NIM, BOPO, and LDR have influence to ROE. Management should improve the company's financial performance, especially on the non performing loan and operational efficiency of the business so that the company can improve to ROE
\end{abstract}

Keywords : Capital Adequacy Ratio (CAR), Non Performing Loan (NPL), Net Interest Margin (NIM), Biaya Operasional/Pendapatan Operasional (BOPO), Loan to Deposit Ratio (LDR), Return on Equity (ROE).

\section{PENDAHULUAN}

Bank merupakan lembaga keuangan dimana kegiatan utamanya yaitu menghimpun dana dari masyarakat, menyalurkan dana kepada masyarakat, serta memberikan jasa di bidang perbankan lainnya atau berperan sebagai perantara antara pihak-pihak yang memiliki kelebihan dana dengan pihak-pihak yang membutuhkan dana. Perbankan adalah industri keuangan yang berfungsi untuk menghimpun dana yang kurang produktif dari masyarakat dan menyalurkannya menjadi kredit bagi dunia usaha. Salah satu pihak yang perlu mengetahui kinerja dari sebuah bank adalah investor karena semakin baik kinerja bank tersebut maka jaminan keamanan atas dana yang di investasikan juga semakin besar. Dengan menggunakan rasio keuangan, investor dapat mengetahui kinerja suatu bank, karena menghasilkan angka yang lebih obyektif. Salah satu rasio keuangan yang umum digunakan oleh investor sebelum membuat keputusan investasi adalah ROE. Bank yang digunakan investor untuk menginvestasikan dananya salah satunya yaitu Bank devisa. Bank devisa adalah bank yang memperoleh surat penunjukan dari Bank Indonesia untuk dapat menawarkan jasa-jasa bank yang berkaitan dengan mata uang asing tersebut, seperti transfer keluar negeri, jual beli valuta asing, transaksi ekspor-impor, dan jasa-jasa valuta asing lainnya, dengan demikian bank devisa dapat melayani secara langsung transaksi-transaksi dalam skala internasional.

Ada beberapa faktor yang berpengaruh terhadap kinerja bank. Faktor-faktor tersebut pada umunya menggunakan 5 aspek penilaian yaitu CAMEL (Capital, Assets, Management, Earning, Liquiditas). Aspek Capital meliputi Capital Adequacy Ratio (CAR), aspek Assets meliputi Non Performing Loan (NPL), aspek Earning meliputi Net Interest Margin (NIM) dan Biaya Operasional/Pendapatan Operasionl (BOPO), sedangkan aspek Liquiditas meliputi Loan to Deposit Ratio (LDR). Faktor-faktor tersebut menggunakan rasio keuangan, hal ini 
menunjukan bahwa rasio keuangan dapat digunakan untuk menilai kinerja keuangan bank. (Januarti, 2002).

Berdasarkan uraian di atas, maka penelitian ini bertujuan untuk menganalisis pengaruh rasio CAR, NPL, NIM, BOPO, dan LDR terhadap ROE Bank Umum Swasta Nasional Devisa di Indonesia periode 2013-2017.

\section{KERANGKA TEORI}

Return on Equity (ROE). ROE merupakan rasio antara laba sesudah pajak terhadap total ekuitas yang berasal dari setoran modal pemilik, laba tak dibagi dan cadangan lain yang dikumpulkan oleh perusahaan. Analisis ROE sering diterjemahkan sebagai rentabilitas modal sendiri. (Muljono, 1999). ROE merupakan indikator yang amat penting bangi pemegang saham dan calon investor untuk mengukur kemampuan bank dalam memperoleh laba bersih berkaitan dengan pembayaran deviden. Perhitungan rasio ROE menurut SE No. 6/23/DPNP tanggal 31 Mei 2004 sebagai berikut:

$\mathrm{ROE}=\frac{\text { Laba Setelah Pajak }}{\text { Rata-rata } \text { modal inti }} \times 100 \%$

Analisa Kinerja Keuangan Menurut CAMEL. Pendekatan CAMEL merupakan suatu jenis analisis keuangan yang digunakan untuk mengevaluasi kinerja keuangan dan manajerial bank. Rasio CAMEL (Capital, Asset Quality, Management, Earning, dan Liquidity) menggambarkan suatu hubungan atau perbandingan antara jumlah tertentu dengan jumlah lain. Aspek Capital meliputi Capital Adequacy Ratio (CAR), aspek Assets meliputi Non Performing Loan (NPL), aspek Earning meliputi Net Interest Margin (NIM) dan Biaya Operasional/Pendapatan Operasionl (BOPO), sedangkan aspek Liquiditas meliputi Loan to Deposit Ratio (LDR).

Capital Adequacy Ratio (CAR). Menurut Eng (2013) Capital Adequacy Ratio (CAR) adalah rasio kinerja bank untuk mengukur kecukupan modal yang dimiliki bank untuk menunjang aktiva yang mengandung atau menghasilkan risiko, misalnya kredit yang diberikan. Dengan kata lain, Capital Adequacy Ratio (CAR) yaitu rasio kewajiban pemenuhan modal minimum yang harus dimiliki oleh bank dan Capital Adequacy Ratio (CAR) memperlihatkan kemampuan bank dalam memenuhi kecukupan modalnya. Capital Adequacy Ratio (CAR) menjadi indikator untuk melihat tingkat efisiensi dana modal bank yang digunakan untuk investasi.

Non Performing Ratio (NPL). Menurut Christiano, Tommy, dan Saerang (2014) Non Performing Loan (NPL) rasio kredit diproksikan dengan Non Performing Loan (NPL), yang merupakan perbandingan antara total kredit bermasalah terhadap total kredit yang diberikan. Menurut Eng (2013), Non Performing Loan (NPL) adalah perbandingan antara kredit yang bermasalah terhadap total kredit. Non Performing Loan (NPL) merupakan salah satu indikator kunci untuk menilai kinerja fungsi bank. Salah satu fungsi bank adalah sebagai lembaga intermediary atau penghubung antara pihak yang memiliki kelebihan dana dengan pihak yang membutuhkan dana. Rasio ini menunjukan kemampuan manajemen bank dalam mengelola kredit bermasalah. Semakin tinggi rasio ini makan akan semakin buruk kualitas kredit bank, artinya jumlah kredit yang bermasalah semakin besar.

\section{Net Interest Margin (NIM)}

Net Interest Margin (NIM) adalah rasio pendapatan bunga bersih terhadap jumlah kredit yang diberikan (outstanding credit). Pendapatan bunga bersih di peroleh dari bunga yang diterima dari pinjaman yang diberikan dikurangi dengan biaya bunga dari sumber dana yang di 
kumpulkan. Net Interest Margin (NIM) menunjukan kemampuan bank dalam menghasilkan pendapatan dari bunga dengan melihat kinerja bank dalam menyalurkan kredit. Hal ini mengingat pendapatan operasional bank sangat tergantung dari selisih bunga (spread) dari kredit yang disalurkan. Untuk mendapat perolehan NIM yang meningkat, maka perlu menekan biaya dana/biaya bunga yang dibayarkan oleh bank kepada masing-masing sumber dana bank yang bersangkutan.

Operasional / Pendapatan Operasionl (BOPO). BOPO termasuk rasio rentabilitas (earnings). Keberhasilan bank didasarkan pada penilaian kuantitatif terhadap rentabilitas bank dapat diukur dengan menggunakan rasio biaya operasional terhadap pendapatan operasional. (Kuncoro dan Suhardjono, 2002). Rasio biaya operasional digunakan untuk mengukur tingkat efisiensi dan kemampuan bank dalam melakukan kegiatan operasinya. Rasio Biaya Operasional terhadap Pendapatan Operasional (BOPO) sering disebut rasio efisiensi digunakan untuk mengukur kemampuan manajemen bank dalam mengendalikan biaya operasional terhadap pendapatan operasional. Semakin besar rasio ini berarti semakin tidak efisien bank tersebut dalam beroperasi (Eng, 2013).

Loan to Deposit Ratio (LDR). Dendawijaya, 2005 dalam Eng (2013) menyatakan bahwa Loan to Deposit Ratio (LDR) merupakan rasio antara seluruh jumlah kredit yang diberikan bank dengan dana yang diterima oleh bank. Loan to Deposit Ratio (LDR) digunakan untuk menilai likuiditas suatu bank dengan cara membagi jumlah kredit dengan jumlah dana. Jika bank dapat menyalurkan seluruh dana yang dihimpun memang akan menguntungkan, namun hal ini terkait resiko apabila sewaktu-waktu pemilik dana menarik dananya atau pemakai dana tidak dapat mengembalikan dana yang dipinjamnya. Sebaliknya, apabila bank tidak menyalurkan dananya maka bank juga akan terkena resiko karena hilangnya kesempatan untuk memperoleh keuntungan.

\section{PENELITIAN TERDAHULU}

Penelitian Indri Astuti Widayani (2005) bertujuan untuk menguji variabel CAR, LDR, BOPO, NPL, dan DER terhadap ROE pada perusahaan perbankan. Obyek penelitian yang digunakan adalah Bank Umum di Indonesia terdiri atas 5 bank persero, 76 bank umum swasta nasional baik bank umum swasta nasional devisa dan bank umum swasta nasional non devisa. Hasil penelitian menunjukan CAR, LDR, BOPO, NPL dan DER secara bersama-sama terbukti memiliki pengaruh signifikan terhadap ROE Bank Umum di Indonesia. CAR, LDR, BOPO dan DER secara parsial memiliki pengaruh yang signifikan terhadap ROE, sedangkan NPL memiliki pengaruh yang tidak signifikan terhadap ROE Bank Umum di Indonesia.

Peneltian Sahata Pardomuan Sidabutar (2007) bertujuan untuk menguji variabel kepemilikan institusi, NPM, DER, BOPO, dan GWM terhadap ROE. Obyek penelitiannya adalah 25 perusahaan perbankan yang terdaftar di BEI. Hasil penelitian menunjukan bahwa NPM, DER, dan GWM secara parsial memiliki pengaruh positif dan signifikan terhadap ROE, dan BOPO memiliki pengaruh negatif dan signifikan terhadap ROE. Sementara secara bersama-sama kepemilikan institusi, NPM, DER, BOPO, dan GWM terbukti signifikan berpengaruh terhadap ROE perusahaan perbankan yang terdaptar di BEI.

Penelitian Erna Wati (2011) bertujuan untuk menguji variabel BOPO, NIM, GWM, LDR, PPAT, dan NPL terhadap ROE pada bank go public dan non go public di Indonesia. Obyek penelitian yang digunakan adalah bank umum di Indonesia periode 2007-2009 sebanyak 81 perusahaan. Hasil penelitian ini menunjukan bahwa rasio-rasio keuangan bank untuk kategori bank go public (terutama BOPO, NIM, LDR, dan NPL) berpengaruh 
signifikan terhadap ROE, sedangkan untuk kategori bank non go public hanya variabel BOPO, NIM, dan LDR yang berpengaruh terhadap ROE.

Penelitian Anindita Dani Permatasari (2012) bertujuan untuk menguji pengaruh CAR, LDR, GWM, dan Institutional Ownership terhadap ROE. Obyek penelitian ini adalah bank umum konvensional go public di Indonesia periode 2009-2011 sebanyak 23 perusahaan perbankan. Hasil peneltian ini menunjukan LDR, NPL, dan GWM tidak berpengaruh terhadap ROE. Sedangkan variabel CAR, BOPO, dan Institutional Ownership berpengaruh negatif dan signifikan terhadap ROE, sedangkan NIM berpengaruh positif dan signifikan terhadap ROE pada perusahaan perbankan.

Penelitian Gandung Yabureta (2016) bertujuan untuk menguji pengaruh BOPO, CAR, LDR, ROA terhadap ROE pada perusahaan perbankan yang terdaftar di BEI periode 20122014. Obyek penelitian ini adalah 21 perusahaan perbankan dan menggunakan data sekuner yanag telah tersedia. Hasil penelitian ini menunjukan secara pasrisal BOPO, CAR, dan ROA berpengaruh terhadap ROE, sedangkan NPL tidak berpengaruh terhadap ROE. Sementara secara bersama-sama variabel BOPO, CAR, LDR, dan ROA terbukti signifikan berpengaruh terhadap ROE.

\section{Kerangka Pemikiran}

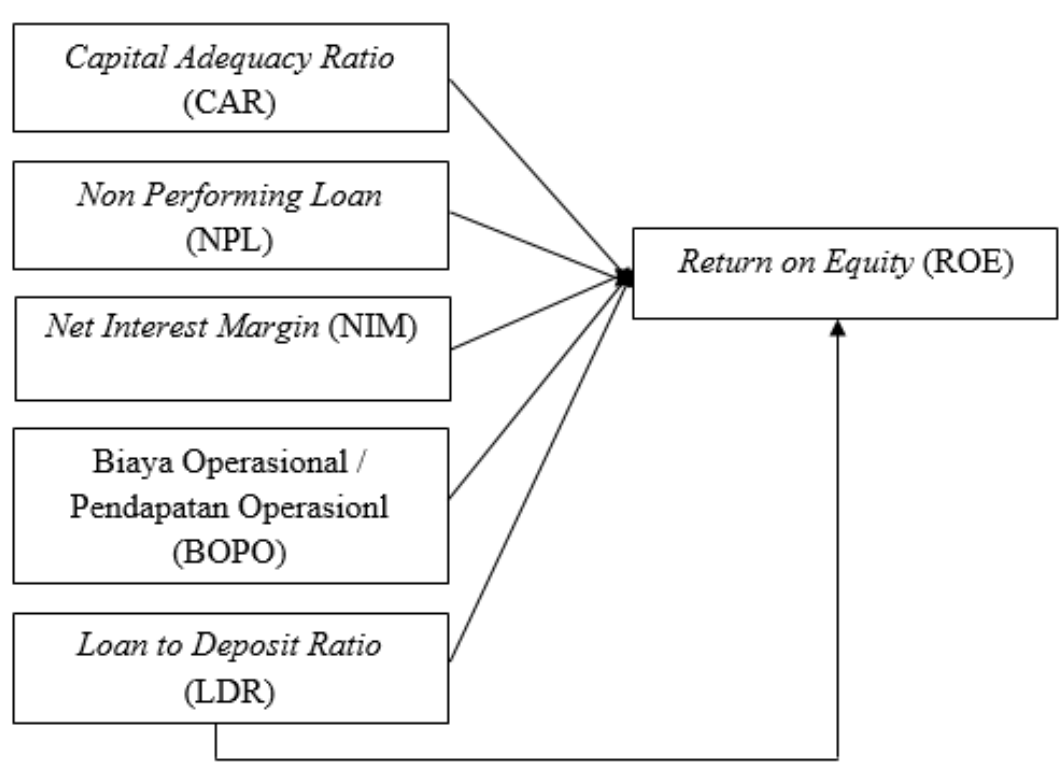

Berdasarkan temuan empiris diatas atau penelitian relevan, kerangka penelitian, maka hipotesis penelitian ini adalah sebagai berikut:

Hipotesis 1 : Capital Adequacy Ratio (CAR) berpengaruh negatif terhadap Return on Equity (ROE).

Hipotesis 2 : Non Performing Loan (NPL) berpengaruh negatif terhadap Return on Equity (ROE).

Hipotesis 3 : Net Interest Margin (NIM) berpengaruh positif terhadap Return on Equity (ROE).

Hipotesis 4 : Biaya Operasional / Pendapatan Operasionl (BOPO) berpengaruh negatif terhadap Return on Equity (ROE).

Hipotesis 5 : Loan to Deposit Ratio (LDR) berpengaruh negatif terhadap Return on Equity (ROE).

Hipotesis 6 : CAR, NPL, NIM, BOPO, LDR secara bersama-sama berpengaruh negatif terhadap Return on Equity (ROE). 


\section{METODOLOGI PENELITIAN}

Jenis data yang diguanakan dalam penelitian ini adalah data sekunder yang berupa data Laporan Keuangan Tahunan dari Bank Umum Swasta Nasional Devisa di Indonesia Periode 2013-2017. Sumber data diperoleh dari website Bank Indonesia dan website Bank Umum Swasta Nasional Devisa. Sedangkan untuk data penelitian merupakan Pooling Data yaitu gabungan antara deret waktu (time series) dan Cross Section selama kurun waktu 2013 sampai dengan tahun 2017, sehingga diperoleh jumlah observasi (titik pengamatan) sebanyak 100, yang didapat dari $20 \times 5$ (perkalian antara jumlah sampel dengan periode tahun pengamatan). Sedangkan populasi yang digunakan dalam penelitian ini sebanyak 35 Bank Umum Swasta Nasional Devisa di Indonesia. Penelitian ini menggunakan metode purposive sampling dengan 2 kriteria sehingga didapatkan 20 perusahaan yang menjadi sampel. Metode pengumpulan data yang digunakan dalam penelitian ini adalah dengan cara melakukan observasi, data yang digunakan adalah data sekunder yaitu daya yang diperoleh dalam bentuk yang sudah jadi berupa publikasi. Berdasarkan waktu pengumpulan, data yang digunakan dalam penelitian ini merupakan data panel.

\section{Metode Analisis Data}

Dalam penelitian disesuaikan dengan kelayakan maupun topik penelitian (Susanto, 2018 hal. 65). Penelitian ini menggunakan analisis data Statistik Deskriptif. Statistik deskriptip memberikan gambaran atau deskripsi suatu data yang dilihat dari nilai rata-rata (mean), standar deviasi, varian, maksimum, minimum, sum, range, kurtosis, dan skewness. Analisis statistik deskriptif digunakan untuk mengetahui gambaran mengenai mekanisme ROE, CAR, NPL, NIM, BOPO, dan LDR pada Bank Umum Swasta Nasional Devisa.

Uji Asumsi Klasik. (1). Uji Heteroskedastisitas, uji ini bertujuan untuk menguji apakah dalam model regresi terjadi ketidaksamaan variance dari residual satu pengamatan ke pengamatan yang lain. Jika variance dari residual satu pengamatan ke pengamatan lain tetap, maka disebut homoskedastisitas, dan jika variance dari residual satu ke pengamatan lain berbeda disebut heteroskedastisitas. Syarat yang harus terpenuhi dalam model regresi adalah tidak adanya gejala heteroskedastisitas. (2). Uji Multikolinearitas, berarti adanya hubungan linear yang sempurna atau pasti antara beberapa atau semua variabel yang menjelaskan model regresi. jika koefisien korelasi antara masing-masing variabel bebas lebih besar dari 0,8, berarti terjadi multikolinearitas dalam model regresi.

Uji Statistik Data Panel. Tahap pemilihan model regresi, yaitu sebagai berikut:

1. Membuat model Pendekatan Kuadrat Terkecil (Commen Effect). Pendekatan kuadran terkecil adalah teknik yang menghubungkan seluruh data time series dan data cross section, kemudian mengestimasi model dengan menggunakan metode ordinary least square (OLS).

2. Membuat model pendekatan Efek Tetap (Fixed Effect Model). Menurut Usman dan Nachrowi (2005), ada variabel-variabel yang tidak semuanya masuk dalam persamaaan model, sehingga memungkinkan adanya intercept yang tidak konstan atau berubah untuk setiap individu dan waktu. Oleh karena itu diperlukan pendekatan efek tetap ini.

3. Membuat model pendekatan Efek Acak (Random Effect Model). Jika pendekatan efek tetap digunakan karena adanya intercept yang tidak konstan atau berubah untuk setiap individu atau waktu, maka pendekatan efek acak ini digunakan untuk mengakomodasi perbedaan setiap individu dan waktu yang disebabkan oleh error.

4. Memilih model estimasi dalam data panel 
- Pemilihan Pooled Least Square (PLS) dengan Fixed Effect Model (FEM). Untuk melakukan pemilihan model ini, digunakan uji Likehood Ratio (chow test), yang digunakan untuk memilih teknik data panel dengan PLS atau FEM.

- Pemilihan Fixed Effect Model (FEM) dengan Random Effect Model (REM). Setelah melakukan uji Likehood Ratio, maka proses selanjutnya adalah melakukan uji Hausman. Uji Hausman dilakukan untuk membandingkan yang mana yang terbaik antara model FEM atau REM.

\section{Uji Hipotesis}

1. Uji Signifikan Variabel Bebas (Uji t) menurut Ghozali (2006), uji signifikansi variabel bebas (Uji statistik t) adalah uji yang menunjukan seberapa besar pengaruh satu variabel bebas individual dalam menerangkan variasi variabel terikat.

2. Uji Signifikan Model (Uji F stat) menurut Ghozali (2006), uji signifikansi model digunakan menguji pengaruh dari seluruh variabel bebas bersama-sama terhadap variabel terikat.

3. Uji $R$ Square \& Adjusted $R$ Square disebut juga koefisien determinasi. Menurut Ghozali (2006), uji ini dilakukan untuk menunjukan seberapa besar pengaruh variabel bebas yang jumlahnya lebih dari satu variabel dalam model penelitian berpengaruh terhadap variabel terikat.

\section{HASIL DAN PEMBAHASAN}

Hasil uji asumsi klasik. Dari hasil uji Breusch-Pagan-Godfrey, Harvey, dan Glejser menunjukkan nilai probabilitas F-Statistik (F-Hitung) lebih kecil dari Alpha $(0,05)$ yaitu 0,0000, artinya, variabel x lebih kecil daripada Alpha $(0,05)$ sehingga dapat disimpulkan, Ho ditolak dan $\mathrm{H} 1$ diterima. Terdapat masalah heteroskedastisitas pada data ini. Sedangkan dari hasil uji multikolinearitas bahwa koefisien korelasi antara masing-masing variabel bebas lebih besar dari 0.8 , berarti terjadi multikolinearitas dalam model regresi.

Analisis model regresi. Permodelan dalam menggunakan teknik regresi pada data dapat menggunakan tiga pendekatan dalam pengelolahannya. Tiga pendekatan tersebut yaitu (1) Metode Common Effect (The Pooled OLS Method); (2) Metode Fixed Effect (FEM); (3) Metode Random Effect (REM).

Pemilihan model estimasi. Pada tahap pertama, peneli akan membandingkan model Common Effect dan Fixed Effect. Pada model common effect diperoleh nilai $R$-Square sebesar 0.750911 atau $75.09 \%$. hal ini berarti kontribusi variabel independent yang digunakan dalam metode common effect maupun menjelaskan variabel dependent adalah sebesar $74.09 \%$. nilai $R$-square $>0.5$, artinya variabel dependent sangat kuat dalam menjelaskan variabel independent. Model common effect tersebut akan dibandingkan dengan model fixed effect untuk dilihat model manakah yang paling sesuai dengan penelitian ini. Dari hasil model model fixed effect, kelima variabel independent secara bersama-sama berpengaruh signifikan terhadap variabel dependentnya dengan kontibusi sebesar $89.21 \%$, lebih besar dibandingkan dengan model common effect. Kedua model tersebut akan dibandingkan terlabih dahulu sebelum dilanjutkan pada tahap berikutnya. Untuk mengatahui model mana yang lebih baik antara common effect dengan fixed effect maka dilakukan pengujian menggunakan Redundant Fixed Effects Test (Chow Test).

Hasil Pengujian Redundant Fixed Effect Test (Chow Test)

Redundant Fixed Effects Tests

Equation: Untitled 
Test cross-section fixed effects

\begin{tabular}{lrrr}
\hline \hline Effects Test & Statistic & d.f. & Prob. \\
\hline \hline Cross-section F & 5.165240 & $(19,75)$ & 0.0000 \\
Cross-section Chi-square & 83.660981 & 19 & 0.0000 \\
\hline \hline
\end{tabular}

Dari hasil dari uji Redundant Fixed Effect Test didapatkan nilai Cross-section $F$ adalah 0.0000 atau lebih kecil dari 0.05. maka Fixed Effect Model merupakan model yang lebih baik dari Common Effect Model. Namun hal ini belum merupakan hasil akhir atas metode pengelolahan data. Gujarati (2003) menyatakan apabila jumlah data cross section (n) lebih besar dari jumlah data time series (T) maka perlu digunakan metode random effect dalam mengelolah data. Maka penelitian akan dilanjutkan dengan uji model antara fixed effect dengan random effect. Dari hasil model random effect, kelima variabel independent secara bersama-sama berpengaruh signifikan terhadap variabel dependentnya dengan kontribusi sebesar $75.01 \%$, lebih kecil di bandingkan dengan model fixed effect. Peneliti akan membandingkan antara model fixed effect dengan model random effect menggunakan uji Hausman Specification Test.

Hasil Pengujian Hausman Test

Correlated Random Effects - Hausman Test

Equation: Untitled

Test cross-section random effects

\begin{tabular}{llrr}
\hline \hline Test Summary & $\begin{array}{l}\text { Chi-Sq. } \\
\text { Statistic }\end{array}$ & Chi-Sq. d.f. & Prob. \\
\hline \hline Cross-section random & 0.868897 & 5 & 0.9724 \\
\hline \hline
\end{tabular}

Dari hasil uji Hausman Test nilai profitability pada Cross-section randmon adalah 0.9724 atau lebih besar dari 0.05. Berdasarkan pengujian yang dilakukan di atas, maka metode yang dipilih adalah Random Effect sebagai model yang lebih baik digunakan untuk mengestimasi data panel pada penelitian ini.

\section{Uji Hipotesis.}

Hasil Uji secara Parsial (Uji t)

Dependent Variable: ROE

Method: Panel EGLS (Cross-section random effects)

Date: 05/31/18 Time: 07:51

Sample: 20132017

Periods included: 5

Cross-sections included: 20

Total panel (balanced) observations: 100

Swamy and Arora estimator of component variances

\begin{tabular}{cccccc}
\hline \hline Variable & Coefficient & Std. Error & t-Statistic & Prob. \\
\hline \hline CAR & 0.328681 & 0.266262 & 1.234428 & 0.2201 \\
\hline NPL & -1.625078 & 0.611115 & -2.659202 & 0.0092 \\
\multicolumn{2}{c}{14} & &
\end{tabular}




\begin{tabular}{crrrr} 
NIM & 0.479728 & 1.146396 & 0.418466 & 0.6766 \\
BOPO & -0.598252 & 0.072759 & -8.222414 & 0.0000 \\
LDR & -0.034059 & 0.111638 & -0.305084 & 0.7610 \\
C & 0.590679 & 0.143112 & 4.127384 & 0.0001 \\
\hline
\end{tabular}

Berdasarkan hasil uji t, dapat di uraikan persamaan regresi berganda sebagai berikut: $\mathrm{Y}(\mathrm{ROE})=0.590679+0.328681(\mathrm{CAR})-1.625078(\mathrm{NPL})+0.479728(\mathrm{NIM})-0.598252$ (BOPO) -0.034059 (LDR)

\section{Hasil Uji F}

Effects Specification

\begin{tabular}{lrc} 
& S.D. & Rho \\
\hline \hline Cross-section random & 0.093404 & 0.5387 \\
Idiosyncratic random & 0.086437 & 0.4613 \\
\hline \hline
\end{tabular}

\begin{tabular}{llll}
\hline \hline & Weighted Statistics & \\
\hline \hline R-squared & 0.750125 & Mean dependentt var & 0.009109 \\
Adjusted R-squared & 0.736834 & S.D. dependentt var & 0.164749 \\
S.E. of regression & 0.084516 & Sum squared resid & 0.671438 \\
F-statistic & 56.43766 & Durbin-Watson stat & 1.579732 \\
Prob(F-statistic) & 0.000000 & & \\
\hline \hline
\end{tabular}

Sedangkan berdasarkan uji F, nilai Prob (F-Statistic) pada penelitian ini adalah sebesar 0.000000 atau $<0.05$. Dari hasil pengujian tersebut dapat disimpulkan bahwa seluruh variabel independent secara bersama-sama berpengaruh terhadap variabel dependentnya.

\section{Pembahasan}

Dari hasil persamaan regresi liniear berganda tersebut di atas maka dapat dianalisis sebagai berikut:

1. Uji Hipotesis Pertama, dari perhitungan uji secara parsial diperoleh t hitung sebesar 1.234428 dan nilai signifikansi sebesar 0.2201. Dengan nilai signifikansi $>0.05$ hipotesis H1o diterima, sehingga dapat disimpulkan CAR tidak memiliki pengaruh terhadap ROE pada Bank Umum Swasta Nasional Devisa. penelitian ini bertolak belakang dengan penelitian yang dilakukan oleh Widayani (2005) yang menyimpulkan bahwa CAR berpengaruh negatif terhadap ROE.

2. Uji Hipotesis Kedua, dari perhitungan uji secara parsial dengan tingkat keyakinan penelitian sebesar 95\% diperoleh t hitung sebesar -2.659202 dan nilai signifikansi sebesar 0.0092. dengan nilai signifikansi $<0.05$ hipotesis $\mathrm{H} 2 \mathrm{a}$ diterima, sehingga dapat disimpulkan NPL berpengaruh negatif dan signifikan terhadap ROE pada Bank Umum Swasta Nasional Devisa. Hal ini konsisten dengan penelitian yang dilakukan oleh Erna Wati (2011) yang menyatakan bahwa NPL berpengaruh negatif terhadap ROE.

3. Uji Hipotesis Ketiga, dari perhitungan uji secara parsial diperoleh t hitung sebesar 0.418466 dan nilai signifikansi sebesar 0.6766. dengan nilai signifikansi $>0.05$ hipotesis H3o diterima, sehingga dapat disimpulkan NIM tidak memiliki pengaruh terhadap ROE pada Bank Umum Swasta Nasional Devisa. penelitian ini bertolak 
belakang dengan penelitian yang dilakukan oleh Erna Wati (2011) yang menyimpulkan bahwa NIM berpengaruh positif terhadap ROE.

4. Uji Hipotesis Keempat, dari perhitungan uji secara parsial dengan tingkat keyakinan penelitian sebesar 95\% diperoleh t hitung sebesar -8.222414 dan nilai signifikansi sebesar 0.0000. dengan nilai signifikansi $<0.05$ hipotesis $\mathrm{H} 4 \mathrm{a}$ diterima, sehingga dapat disimpulkan BOPO berpengaruh negatif dan signifikan terhadap ROE pada Bank Umum Swasta Nasional Devisa. Hal ini konsisten dengan penelitian yang dilakukan oleh Erna Wati (2011) yang menyatakan bahwa BOPO berpengaruh negatif terhadap ROE.

5. Uji Hipotesis Kelima, dari perhitungan uji secara parsial dengan tingkat keyakinan penelitian sebesar 95\% diperoleh t hitung sebesar -0.305084 dan nilai signifikansi sebesar 0.7610. dengan nilai signifikansi > 0.05 hipotesis H5o diterima, sehingga dapat disimpulkan LDR tidak memiliki pengaruh terhadap ROE pada Bank Umum Swasta Nasional Devisa. Hal ini konsisten dengan penelitian yang dilakukan oleh Permatasari (2012) yang menyatakan bahwa NPL berpengaruh negatif terhadap ROE. Dari hasil pengujian hipotesis di atas, dapat disimpulkan, CAR, NIM, dan LDR tidak berpengaruh terhadap ROE, sedangkan NPL dan BOPO berpengaruh negatif signifikan terhadap ROE.

\section{KESIMPULAN DAN SARAN}

Berdasarkan analisis dan pembahasan pengaruh CAR, NPL, NIM, BOPO, dan LDR terhadap ROE pada perusahaan perbankan, maka ditarik kesimpulan:

a. Dari hasil pembahasan atas pengujian hipotesis mengenai pengaruh CAR terhadap ROE pada perusahaan perbankan menunjukan bahwa variabel CAR tidak berpengaruh terhadap ROE perusahaan perbankan yang terdaftar di Bank Indonesia, sehingg hipotesis 1 ditolak.

b. Dari hasil pembahasan atas pengujian hipotesis mengenai pengaruh NPL terhadap ROE pada perusahaan perbankan menunjukan bahwa variabel NPL berpengaruh negatif terhadap ROE perusahaan perbankan yang terdaftar di Bank Indonesia, sehingg hipotesis 2 diterima.

c. Dari hasil pembahasan atas pengujian hipotesis mengenai pengaruh NIM terhadap ROE pada perusahaan perbankan menunjukan bahwa variabel NIM tidak berpengaruh terhadap ROE perusahaan perbankan yang terdaftar di Bank Indonesia, sehingg hipotesis 3 ditolak.

d. Dari hasil pembahasan atas pengujian hipotesis mengenai pengaruh BOPO terhadap ROE pada perusahaan perbankan menunjukan bahwa variabel BOPO berpengaruh negatif terhadap ROE perusahaan perbankan yang terdaftar di Bank Indonesia, sehingg hipotesis 4 diterima.

e. Dari hasil pembahasan atas pengujian hipotesis mengenai pengaruh LDR terhadap ROE pada perusahaan perbankan menunjukan bahwa variabel LDR tidak berpengaruh terhadap ROE perusahaan perbankan yang terdaftar di Bank Indonesia, sehingg hipotesis 5 ditolak.

f. Dari hasil pembahasan atas pengujian 5 hipotesis menunjukan bahwa secara bersamasama variabel CAR, NPL, NIM, BOPO, dan LDR berpengaruh terhadap ROE perusahaan perbankan yang terdaftar di Bank Indonesia, sehingga hipotesis 6 diterima.

Saran-saran yang dapat diberikan berdasarkan kesimpulan penelitian adalah sebagai berikut: 
1. Bagi penelitian selanjutnya diharapkan jumlah observasi lebih banyak dengan tingkat kebenaran beserta angka.

2. Diharapkan tidak memperhatikan CAR, NIM, dan LDR karena tidak memiliki pengaruh terhadap ROE.

3. Lebih fokus terhadap NPL dan BOPO karena memiliki pengaruh negatif terhadap ROE.

\section{DAFTAR PUSTAKA}

Bank Indonesia. (2004). Surat Edaran Bank Indonesia Nomor 6/23/DPNP Perihal Sistem Penilaian Tingkat Kesehatan Bank.

Christiano, M., Tommy, P., \& Saerang, I. (2014). "Analisis Terhadap Rasio-Rasio Keuangan untuk Mengukur Profitabilitas pada Bank-Bank Swasta yang Go-Public Di Bursa Efek Indonesia”. Jurnal EMBA. Vol 2 No. 4 Desember 2014, Hal 817-830

Eng, Tan Sau. (2013). "Pengaruh NIM, BOPO, LDR, NPL \& CAR Terhadap ROA Bank Internasional dan Bank Nasional Go-Public Periode 2007-2011". Jurnal Dinamika Manajemen. Vol 1 No. 3

Ghozali, Imam. (2006). "Aplikasi Analisis Multivariate Dengan Program SPSS”. Cetakan Keempat. Semarang: Badan Penerbit Universitas Diponegoro

Gujarati, Damodar, (2003). "Ekonometri Dasar". Terjemahan: Sumarno Zain, Jakarta: Erlangga

Herdiningtyas, W., \& Almiliah. L., S. (2005). "Analisis Rasio Camel Terhadap Prediksi Kondisi Bermasalah Pada Lembaga Perbankan Periode 2000-2002. Jurnal Akuntansi dan Keuangan. Vol 7 No. 2 November

Januarti, Indira (2002). "Variabel Proksi CAMEL dan Karakteristik Bank Lainnya untuk Memprediksi Kebangkrutan Bank di Indonesia", Junal Bisnis Strategi, Vol.10

Mudrajad, K., \& Suhardjono. (2002). “Manajemen Perbankan”. Yogyakarta. BPFE.

Muljono, Teguh Pudjo. (1999). “Analisa Laporan Keuangan Untuk Perbankan”, Jakarta: Djambatan

Nachrowi, Nachrowi, D., \& Usman, H. (2005). "Penggunaan Teknik Ekonometrika". Jakarta: PT Raja Grafindo Persada. 2005

Permatasari, Anindita Dani. (2012). "Analisis Pengaruh CAR, LDR, NIM, NPL, BOPO, GWM dan Instututional Ownership Terhadap Profitabilitas". Skripsi. Semarang. Universitas Diponegoro.

Sidabutar, Sahata Pardomuan. (2007). "Analisis Pengaruh Kepemilikan Institusi, Net Profit Margin, Debt to Equity Ratio, dan Rasio-Rasio Bank Terhadap Return on Equity". Tesis. Semarang. Universitas Diponegoro.

Susanto, Eko Harry. (2018). “Komunikasi Manusia: Teori dan Praktek Dalam Penyampaian Gagasan”. Jakarta: Mitra Wacana Media

Wati, Erna. (2011). "Analisis Pengaruh BOPO, NIM, GWM, LDR, PPAT, dan NPL Terhadap ROE Pada Bank Go Public dan Non Go Public di Indonesia Periode Tahun 20072009”. Tesis. Semarang. Universitas Diponegoro.

Widayani, Indri Astuti. (2005). "Analisis Faktor-Faktor yang Mempengaruhi

Profitabilitas Perbankan Periode 2000-2002”. Tesis. Semarang.

Universitas Diponegoro.

Yanureta, Gandung. (2016). "Analisis Pengaruh BOPO, CAR, LDR, ROA Terhadadp Keputusan Berinvestasi Pada Perusahaan Perbankan yang Terdaftar di BEI Tahun 2012-2014'. Skripsi. Semarang. Universitas Diponegoro. 
